\title{
Required Skills for Teachers: Information Literacy at the Top ${ }^{1}$
}

\author{
Tatiana Sanches \\ Institute of Education, Lisbon University, Lisbon, Portugal \\ tsanchesefpie.ulisboa.pt
}

\begin{abstract}
This study seeks to contribute to a reflection on teachers' training and professional development in the field of information literacy, in Portugal. Aspects regarding teacher training and their role as spreaders of knowledge and multipliers of good practices are problematized. UNESCO's curriculum for teachers and ACRL guidelines are used methodologically as the central thread of this interpretation. From here we seek to explain how a higher education institution - an Institute of Education -, which is devoted to the professional development of educators, including teachers, has engaged in information literacy actions through training interventions, in recent years. The study concludes that through sharing and dialogue within the librarian profession, but also within the sphere of education professionals - teachers and trainers - the best training practices in university libraries can be consolidated. Finally, certain points for reflection and debate concerning this theme are proposed.
\end{abstract}

Keywords: Information Literacy, Teacher Education, Librarian Teacher Cooperation, Higher Education, Portugal.

\section{$1 \quad$ Introduction}

The increase of compulsory education has created optimal conditions for more students to reach higher education, mobilising a great mass of teaching professionals all over the world and posing countless challenges for the teaching profession, especially in the transition of the 20th to the 21 st century, including:

- teaching has become student-centered

- there is greater access to information

- more choice and diversity of training courses

- there is an interception of the digital era in teaching tools

- training interventions for online environments have been created and adapted

1 The final publication is available at link.springer.com, at: https://link.springer.com/chapter/10.1007/978-3-319-74334-9 65 
The explosion of information, in a multimedia and digital context, has become a fertile area for exploring, communicating and spreading information, thus enabling new knowledge to be learned, created and taught. This scenario poses questions regarding the skills future and in-service teachers must acquire and develop. These skills will give them more intervention capacity, because not only will they benefit their role as spreaders of information, but they will allow them to develop the ways in which they learn and are updated. Thus pre-service and in-service teachers are agents and subjects of new learning.

The study now presented intends to explore these characteristics and the way teachers can prepare specifically for dealing with information, developing their information literacy. On one hand, this includes knowing how to search, choose, organise, evaluate and present information in an ethical and legal manner, and giving them better conditions to communicate it. On other hand, it will benefit teachers because information skills will allow them to deal with teaching and learning environments that are constantly developing, and it will support them in their professional development and in their lifelong learning. In the first part of this article, a reflection is conducted on the impact of information literacy in the educational and learning context, analysing processes and trajectories teachers may explore while developing their skills, particularly information literacy. In the second part, a case of specific information literacy training course in Portugal, directed towards teachers and conducted by a university library, is presented. Both sections aim to show how Information Literacy proves to be a set of vital required skills for teachers.

\section{Information literacy as a fundamental skill for teachers}

In 2006 the European Parliament [1] recommended a set of key skills for lifelong learning, an important milestone in the definition of a comprehensive strategy in the field of education, where skills are defined as a blend of knowledge, abilities and attitudes that are suitable for each performance context. Key skills are said to be those that support personal fulfillment, social inclusion, active citizenship and employment. The debate became very interesting as some authors spoke of the importance of preparing teachers for the challenges of the $21^{\text {st }}$ century, namely in Europe, so as to act in a changing society. Persson [2, p.13] stated that "If professionals in education are to prepare an even more diverse group of learners for much more challenging work they will need substantially more/new knowledge and radically different lifelong skills than most now have". Some years later, a study [3] concluded that learning objectives will focus more on skills than on knowledge, that learning will be more adapted to the needs of real life and that individuals will be more active and connected to their environment, and therefore teachers themselves will become lifelong learners. Flores and Coutinho [4, p.7] also mentioned that teachers' work implies new ways of regarding teaching, knowledge and the role of schools and teachers. Perrenoud [5] had already looked into what are the essential skills for teachers, having highlighted innovative practices and also emerging skills, that is, those that should guide pre-service and in-service training, 
contribute to the fight against school underachievement and, on the other hand, develop citizenship, resort to research and emphasise reflective practice. In fact, teachers must pay attention to their professional training and development, as has also been demonstrated by the research on the theme [6]. The scope and responsibility of functions is clear, as well as perception of the social impact of this profession.

This initial approach shows that teachers are key actors in a changing social context, particularly in an information society. These changes have greater impact on learning and are precisely based on the exchange of information and on the way knowledge is generated, but also how the information is searched, chosen and used. That is why the expertise to deal with information in a vital skill for any citizen in the $21^{\text {st }}$ century, especially for professionals whose primary material is information and knowledge.

New teaching and learning practices are also important for this reflection. Studentcentred teaching requires the use of digital and multimedia-based learning resources. Digital libraries and repositories facilitate the reuse of digital content, allowing access to a variety of sources and boosting the formation of critical thinking and the creation of more complex ideas, while encouraging students to use the resources and reinterpret them [7]. To develop all these skills Information Literacy is crucial. The American Library Association, through its Association of College and Research Libraries Division [8], defines this concept, explaining that an individual qualified with information skills should be

- capable of determining the need for information and its extent

- accessing information efficiently and effectively

- critically evaluating information and its sources

- incorporating the information chosen in his knowledge base

- using the information effectively to fulfill a specific objective

- understanding the economic, legal and social implications of the use of information

- $\quad$ knowing how to access and use it ethically and legally.

The same document adds that the development of skills within information literacy makes individuals more capable of dealing with information in the several spheres of activity throughout life [8]. As Esteves states [9, p.37], the huge amount of information made available to everyone today can be considered to be very positive, as well as an increasingly easier access to the extensive knowledge stored there. On the other hand, the excessive abundance of information makes it indigestible for a single individual and the quality (rigour, validity) of available information is very unequal. So new needs emerge, associated with information processing and organisation and with the adoption of a critical point of view about its quality. The teacher's role also includes promoting the learning of information literacy, seeking to incite in students the attitude needed for the development and practice of skills to be better learners. This is the reason why libraries all over the world are organizing and providing specific training to promote information skills.

Through their official position, two entities - UNESCO and ALA/ACRL - have been legitimizing the importance of information literacy skills in teaching training. Both marked their positions regarding information literacy and its concept, its social influence and the way the educational and technological context affect learning and 
have impact on this profession, stressing the importance of mastering information for effective lifelong teaching and learning. The guiding document Information Literacy Standards for Teacher Education [10, p.1], states that "Teachers play a key role in providing students with diverse opportunities to learn how to use information wisely." This vital document provides tools for teachers so that librarians can prepare specific training for them and, on the other hand, the evaluation of this kind of training can be carried out, with comparable results and benchmarking. Librarians working in higher education, especially in teacher and education professionals' training schools, can plan and implement their training with this specific target audience in mind. The structure followed in this document is exactly the same as the one found in the Information Literacy Competency Standards for Higher Education [8], presenting the information literacy learning standards, which turn into performance indicators and are accompanied by practical examples regarding goals to attain. In turn, UNESCO issued official guidelines that frame and describe the composed concept of Media and Information Literacy (MIL), recently publishing a set of documents which relate the capacity to deal with information and with media in a critical, informed manner: the guiding document Media and Information Literacy: Policy and Strategy Guidelines [11], and the document Global Media and Information Literacy Assessment Framework: Country Readiness and Competencies [12] fit these purposes. Both include the concept of information literacy combined with that of media literacy. The reason for this is the need to provide citizens with the necessary skills to search, experience and benefit from the freedom of expression and of access to information, whatever the support may be. These documents seek to correspond to current convergence trends of radio, television, internet, newspapers, books, archives and physical and digital libraries into one single platform, thus regarded as means to access information, irrespective of the channel. Therefore, information literacy is introduced considering the diverse contexts for its use and with the purpose of fully integrating and developing these skills in personal, educational and social spheres. UNESCO's commitment to promote MIL is visible not only in the above mentioned documents, but also in the document Media and Information Literacy Curriculum for Teachers [13]. This document took into account the importance of integrating MIL in the formal training of teachers, thus enabling a process which aims to reach and develop the capacities of million of young people through their teachers, working as a catalyst of this specific knowledge. Media and information literacy expand the movement for civic education which incorporates teachers as the main agents of change.

\section{Teaching Information Literacy to teachers around the world}

The study of information literacy as a fundamental skill for teachers is not new. For instance, Huang and Yang [14] address the technological changes that have had an impact on the field of education, stressing the need to develop knowledge in teachers, given the challenges, changes and skills that must be developed in an educational digital ecosystem. Although focused on the impact of technologies in schools, Schrum, Niederhauser and Strudler [15] also mention the importance of preparing school leaders, 
teachers and educators for the future, given their decisive role with students in the $21 \mathrm{st}$ century. The increasing prominence of information literacy in teacher training is underlined by Kovalik, Jensen, Schloman and Tipton [16], who stress the teacher's role and responsibility in teaching information literacy, sustaining the idea of becoming proficient in the mastery of this matter and teaching it. Their study presents the results of an inquiry (covering 46 USA higher education establishments), which relates data about teachers' knowledge, inclusion and information literacy evaluation in teacher training programmes, as well as collaboration between teachers and librarians to teach these skills. The conclusions reiterate the importance of including information literacy education in pre-service teacher training curricula. This has been studied in different parts of the globe, with glaringly different implementation speeds in different countries.

In the United States, in Ohio, a cross-sectional study had already been carried out in 2009 at a higher education establishment with teacher training [17]. It reports several implementation phases of the teacher training programme on information literacy, highlighting the close collaboration between librarians and teachers and the success achieved, though there is no standard manner of incorporating information literacy in terms of curricula. In Croatia, a study by Kokic [18] shows how difficult it is to evaluate learning in information literacy in this context. Although there are learning objectives connected to the expected results of information literacy (based on international standards), these are limited. On the other hand, as the syllabi are not yet aligned with the guiding documents, recommendations favour a more consistent integration of these learnings in terms of curricula. In Greece [19], the Department of Primary Education of the School of Education (Aristotle University of Thessaloniki) defined a program to integrate information literacy education in the first years of teacher training courses. After three years of implementation, since 2010-11, the outcome was very positive, one of the students' conclusions being that "the IL course is not an end in itself but an introductory stage in which they learn to utilize IL tools in a context to build on their IL confidence.” [19, p.24]. In Brazil a report describes an experiment [20] consisting of a training workshop for in-service teachers. The idea was to develop information skills in public basic education teachers, considering the absence of programmes integrated in the curriculum and also, according to the authors, considering that information is an enhancer of knowledge. So, if it is developed based on public inclusion policies, it will have positive consequences on education and on a large scale, as an ally in the development of skills, especially for content mediators, as teachers are [20, p.61]. From Russia and Uzbekistan [21] there are also reports already seeking to reflect further on the inclusion of UNESCO's guiding documents, adapting them to the local reality and implementing models that may be integrated in these countries in terms of pre-service teacher training. In light of the same documents, Alves and Varela [22] analyse the trainers' training needs, in this case in Portuguese-speaking African countries. Based on this analysis, they consider UNESCO's [13] model to be the best for media and information literacy training, because it ensures a broader, more adequate learning of the subjects related to information.

Some authors have mentioned the importance of addressing information literacy as a skill to be taught in pre-service teacher training as well as in the professional development teachers should seek to carry out over their career. Shipman, Bannon and Nunes-Bufford [23] refer to this exactly, relating in-service teachers' information search and use habits to training previously carried out during their initial training, thus stating 
that the results of information literacy training are long-lasting, accompanying teachers throughout their professional performance. The importance of information literacy is already recognised as a skill to be integrated in teachers', trainers' and educators' training. This awareness is not only manifest in the experiments reported, as those described above, but also in the prospective questioning of intervenors, and in the theoretical reflections this topic has triggered. For instance, Perzycka's [24] theoretical reflection substantiates the important of studying and applying information literacy more consistently, from the in-depth analysis of the conditions it is made of, as well as from dialogue with theory from which practices may benefit.

\section{A case of specific training in the Portuguese context}

Numerous studies have analysed and reflected upon pre-service teacher training, and Portugal is no exception. Most authors agree that there are training processes that complement each other in pre-service training: the curricular part, based on learning subjects, and training in the context of a professional internship, which seeks to ensure preparedness for professional reality [25]. Silva [26, p. 26] states that teacher training is a continuous, systematic, wholistic, transversal and organised process, present in every moment of the teaching career. The Portuguese law (D.L. no. 240/2001, of 30 August) actually establishes the professional performance profiles of professions related to teaching (including kindergarten teachers and basic and secondary education teachers). Cannas and Moreira [27, p.46] declare that, as the main agents of the educational process, teachers may be the authors of innovative, reflexive action when they participate as protagonists in implementing good pedagogical practices.

The University of Lisbon is the biggest university in Portugal, with 18 Schools (Faculties and Institutes) and around 50,000 students, 3,500 teachers and 2,500 staff. There are 22 academic libraries, organised by themes according to the areas of education and research of each autonomous unit. The Institute of Education, currently with about 900 students, is one of these schools, devoted to research, training in education and training in Portugal. It is important to mention that since 2010, the library of the Institute of Education, which previously depended on a single institution - the Faculty of Psychology and Educational Sciences - has been supporting the research and education of the two institutions created that year - the Faculty of Psychology and the Institute of Education, of the University of Lisbon.

The library has sought to align with international standards, providing two modalities of information literacy training: in the classroom and occasionally via elearning (requested by teachers), and in open enrolment workshops, based on a training programme developed by its librarians. The analysis that follows concerns this last contribution. The experiment carried out by the library of the Faculty of Psychology and Institute of Education has a ten-year record of user training, but this study focuses only on the most recent year. The construction of the current training plan was based on previous experience and on international guiding documents. Considering the ALA and UNESCO documents $[10,13]$, we sought to address all the skills that are part of the requirements for teacher training, relating them to the established standards and to the 
learning goals of each module offered, always bearing in mind their contextual application. The information-literate teacher education student:

1) defines and articulates the need for information and selects strategies and tools to find it.

2) locates and selects information based on its appropriateness to the specific information need and the developmental needs of the students.

3) organizes and analyzes the information in the context of specific information needs and the developmental appropriateness for the audience.

4) synthesizes, processes, and presents the information in a way that is appropriate for the purpose for which information is needed.

5) evaluates discrete pieces of information as well as the entire information seeking process.

6) knows how to ethically use and disseminate information.

The MIL curriculum for teachers is framed based on three content areas:

1. Knowledge and understanding of media and information for democratic discourses and social participation.

2. Evaluation of media texts and information sources.

3. Production and use of media and information.

This training offer seeks to remedy the failings of several students in information literacy and contribute to the development of skills in searching, evaluating and transmitting information, trying to combine both guideline documents, but also considering the ACRL Framework [28].

The preparation of this intervention took into account the needs indicated by several users and was formulated in an appealing way, seeking to match the level of education and the level of complexity inherent to each training proposal. Work started on the training plan in order to change the organisation established the previous year as regards its curricular plan, length, schedule, evaluation and promotion. The didactic materials were also reconsidered. The presentation text available in the institutional sites to publicise these sessions was composed as follows:

The library continues to promote workshops aimed at developing skills in the good use of

information resources, especially designed to support academic goals. The volume of information currently available requires students have the necessary skills to search, evaluate, select, use and present information in an ethical and effective manner. That is why we have designed a programme for the continuous development of these skills:

1 - Searching and selecting in electronic resources

2 - Quoting and referencing with the APA $6^{\text {th }}$ norm

3 - Managing bibliographic references with Endnote web

4 - Organising information for theses and dissertations

5 - Oral and Power Point presentations

The main feature is related to the idea that information literacy responds to several requests which, in the case of these students, may be divided into two assumptions. One regards academic goals: completing work for different subjects; obtaining an academic degree, by presenting a dissertation or thesis at the end of the course; conducting research, for which bibliography must be managed in depth (showing information has value [28]). The other regards the need for future teachers to incorporate what they learn into their scope of knowledge, then to retransmit it and adjust it in different contexts for their own future pupils (showing scholarship as conversation [28]). 
Alongside the information skills practiced in a training context (the rooms where the training takes place are equipped with computers so students can carry out exercises), we also considered it important to complement training with different examples, in view of future adjustment needs of information literacy to different contexts.

Based on a systematic evaluation performed at the end of the sessions, the outcome of the training sessions carried out in 2016/2017 was very positive. This evaluation used a Lickert scale, with scores between 1 (dissatisfied) and 4 (very satisfied), comprising the following ten issues:

- General quality of the trainer's exposition

- Content organisation

- Relevance of the topics covered

- Clarity of the exposition

- Adequacy of training to student needs

- Trust in the information provided by the trainer

- Supporting documentation

- Quality of the tutorials presented

- Adequacy of training to students' level of knowledge

- Comfort of the room.

The results of the questionnaires given to users in every session are proof of the positive feedback regarding this programme. In 2017 a group of five programmes were carried out, each one containing five two-hour workshops. During the first semester of 2017,25 sessions were thus carried out, taught by three librarians who trained a total of 207 students, having had a 95 percent global average rating in terms of satisfaction.

Table 1. Information literacy programme, taught during the 1st semester of 2017.

\begin{tabular}{lcc}
\hline Workshops taught & Students involved & Satisfaction \\
\hline 1. Searching and selecting in electronic resources & 35 & $92 \%$ \\
2. Quoting and referencing with the APA 6th norm & 50 & $95 \%$ \\
3. Managing bibliographic references with Endnote & 47 & $95 \%$ \\
web & & $95 \%$ \\
4. Organising information for theses and dissertations & 48 & $97 \%$ \\
5. Oral and Power Point presentations & 27 & \\
\hline
\end{tabular}

Besides information retrieval or organisation strategies, another aspect introduced concerns strategies for presenting information, providing some practical ideas to deal with communicating and presenting ideas (showing authority is constructed and contextual, and information creation as a process [28]). This evaluation indicated the consolidation of our training practices and certainly the trainers' commitment to helping users in a personalised manner to develop their information literacy skills.

\section{$5 \quad$ Final remarks}

All formal learning requires the use of resources based on information. Following 
librarians' steps, teachers seek to facilitate the reuse of content, allowing access to a variety of sources and enhancing the development of critical thinking and the creation of more complex ideas, as they encourage students to use and reinterpret resources [29]. Students and teachers use information resources to carry out much of their activity, which implies the capacity to understand, access, evaluate, use and manage a vast range of documents. Hence teachers need to devote some time to learning new information organization, management tools and ways to present academic work. In turn, librarians must have thorough knowledge of these topics and allow them to be taught so they can be reproduced, particularly when being taught to teachers.

We sought to show how important it is to recognise the teacher's role as a multiplier of information literacy. The paper focused on the importance of teachers' information literacy and discussed a training intervention developed by a higher education institution in Portugal to engage information literacy skills and competencies in the professional development of educators. The literature review and observation of practices converge towards the same conclusions: the key importance of information literacy in teacher education and how teachers themselves are aware of it. Therefore, librarians must make their contribution, providing information resources and the training needed to use them to the full.

Everyone involved should understand to what extent they need to develop greater expertise, particularly if they are leading similar processes, seeking to correspond to these specific needs. Such sharing should be based above all on dialogue between these two professionals - librarians and teachers - so that both can converge towards common goals. As this alignment of interests and efforts is essential, in the future it will be important that international documents are converted into national guidelines in Portugal, consolidating and standardising the training offer for teachers, which would increase the scope and impact of information literacy. The actions librarians can develop at this level are fundamental, for they are the basis for the creation and development of transversal skills in lifelong learning, for which teachers are indispensable actors and partners.

\section{References}

1. European Parliament and the Council: Recommendation of the European Parliament and the Council of 18 December 2006 on key competences for lifelong learning. In: Official Journal of the European Union, L394 (2006).

2. Persson, M.: A vision of European teaching and learning: perspectives on the new role of the teacher. The Learning Teacher Network, Karlstad (2006)

3. Ala-Mutka, K., Redecker, C., Punie, Y., Ferrari, A., Cachia, R., \& Centeno, C.: The future of learning: European teachers' visions. In: Report on a foresight consultation at the 2010 eTwinning Conference. Seville. (2010, February)

4. Flores, M. A., Coutinho, C.: Formação e trabalho docente: tendências e desafios atuais. De Facto, Sto. Tirso (2014)

5. Perrenoud, P.: Dix nouvelles compétences pour enseigner: invitation au voyage. ESF, Paris (1999)

6. Conceição, C., Sousa, O.: Ser professor hoje: o que pensam os professores das suas competências. Revista Lusófona de Educação, 20, 81-89 (2012).

7. McGill, L.: Transforming curriculum delivery through technology": JISC Programme Synthesis Report (2011). Accessed April 24, 2017, 
http://www.jisc.ac.uk/media/documents/programmes/curricul umdelivery/curriculumdeliveryfinalreport.pdf

8. ALA: Information Literacy Competency Standards for Higher Education. Association of College and Research Libraries, American Library Association, Chicago (2000), http://www.ala.org/acrl/sites/ala.org.acrl/files/content/ standards/standards.pdf

9. Esteves, M.: Construção e desenvolvimento de competências profissionais dos professores em contexto de aprendizagem em rede. In: O desenvolvimento profissional docente em discussão. M. F. Pryjma, O. S. Oliveira (Eds.), p. 23-46. UTFPR, Curitiba, (2016)

10. ALA: Information Literacy Standards for Teacher Education. Association of College and Research Libraries, American Library Association, Chicago (2011). http://www.ala.org/acrl/sites/ala.org.acrl/files/content/ standards/ilstandards_te.pdf

11. UNESCO: Media and Information Literacy: Policy and Strategy Guidelines. UNESCO, Paris (2013), http: / / unesdoc.unesco.org/images / 0022 / 002256 / $225606 \mathrm{e} \cdot \mathrm{pdf}$

12. UNESCO: Global Media and Information Literacy Assessment Framework: Country Readiness and Competencies. UNESCO, Paris (2013), http: //www . uis. unesco.org/Communication/Documents/mediaand-information-literacy-assessment-framework.pdf

13. Wilson, C. et al.: Media and Information Literacy Curriculum for Teachers. UNESCO, Paris (2011), http://www. unesco.org/new/fileadmin/MULTIMEDIA /HQ/CI/CI/pdf/media_and_information_literacy_curriculum_f or teachers en.pdf

14. Huang, R., Yang, J.: Digital learners and digital teachers: challenges, changes, and competencies. In: Competencies in teaching, learning and educational leadearship in the digital age. J. M. Spector et al. (Eds.), p. 47-56. Springer, Switzerland, (2016)

15. Schrum, L., Niederhauser, D. S., Strudler, N.: Competencies, challenges, and changes: a US perspective on preparing twenty-first century teachers and leaders. In: Competencies in teaching, learning and educational leadearship in the digital age. J.

M. Spector et al. (Eds.), p. 47-56. Springer, Switzerland, (2016)

16. Kovalik, C. L., Jensen, M. L., Schloman, B., Tipton, M.: Information Literacy, collaboration, and teacher education. Communications in Information Literacy, 4(2), 145-169 (2010).

17. Earp, V.: Integrating information literacy into teacher education: a successful grant project. Behavioral \& Social Sciences Librarian, 28(4), 166-178 (2009).

18. Kokic, I. B.: Information literacy for future teachers. World Journal of Education, 2(1), 45-54, (2012).

19. Bougatzeli, E., Togia, A., Papadimitriou, E.: Developing an information literacy course for teacher education students in Greece. The Internacional Journal of Literacies. 21, 17-26, (2015).

20. Silva Neto, C. E., Freire, G. H.A..: Competência em informação: relato de experiência. RACIn . 2(2), 44-63, (2014).

21. Gendina N.: Integrating the Personal Information Culture Concept and the Idea of Media and Information Literacy Offered in the UNESCO Curriculum for Teachers: Experiences of Russia and Uzbekistan. In: Kurbanoğlu S. et al. (eds). Information Literacy: Key to an Inclusive Society. ECIL 2016. Communications in Computer and Information Science, vol 676. 543-554, Springer, Cham 
22. Alves, F. M. M., Varela, A. V.: Formação de formadores em Media and Information Literacy (MIL) para países lusófonos africanos. Revista Brasileira de Biblioteconomia e Documentação. 13 (n. especial), 254-271 (2017).

23. Shipman, T., Bannon, S. H., Nunes-Bufford, K.:The information-seeking habits of inservice educators. College and Research Libraries, 76 (2), 120-135, (2015).

24. Perzycka, E.: Teacher's learning processes of information competences in the network society - proposed theoretical model and methodological solutions. The New Educational Review, 40(2), 180-188 (2015).

25. Loss, A. S., Caetano, A. P. V., Ponte, J. P. Formação de Professores no Brasil e em Portugal: pesquisas, debates e práticas. Annris, Curitiba (2015).

26. Silva, C.: Tornar-se professor ou o itinerário formativo: entre formação inicial, indução profissional e formação contínua. In: Flores, M. A., Carvalho, M. L., Silva, C. (eds.). Formação e aprendizagem profissional de professores: contextos e experiências. p. 1740. De Facto, St. Tirso (2016).

27. Cannas, A. C., Moreira, J. A.: O perfil profissional docente em contextos educativos diferenciados. Whitebooks, St. Tirso (2015).

28. Association of College and Research Libraries [ACRL]: Framework for information literacy for higher education. (2015).

http://www.ala.org/acrl/standards/ilframework

29. McGill, L.: Transforming curriculum delivery through technology: JISC Programme Synthesis Report.(2011) http://www.jisc.ac.uk/media/documents/ programmes/curriculumdelivery/curriculumdeliveryfinalrepo $r t \cdot p d f$ 